\title{
Smart Micro-Grid Performance using Renewable Energy
}

\author{
Bangun Novianto ${ }^{1}$, Kamaruddin Abdullah ${ }^{1 *}$, Aep Saepul Uyun ${ }^{1}$, Erkata Yandri ${ }^{1}$, \\ Syukri Muhammad Nur ${ }^{1}$, Herry Susanto ${ }^{1,2}$, Zane Vincēviča-Gaile ${ }^{3}$, \\ Roy Hendroko Setyobudi ${ }^{1,4}$, and Yanuar Nurdiansyah ${ }^{5}$ \\ ${ }^{1}$ Graduate School of Renewable Energy, Darma Persada University, \\ Jl. Taman Malaka Selatan No.22, Jakarta Timur, 13450, Indonesia \\ ${ }^{2}$ Department of Mechanical Engineering, Darma Persada University, \\ Jl. Taman Malaka Selatan No.22, Jakarta Timur, 13450, Indonesia \\ ${ }^{3}$ Department of Environmental Science, University of Latvia, \\ Jelgavas Street 1, Room 302, Riga LV-1004, Latvia \\ ${ }^{4}$ Department of Agriculture Science, Postgraduate Program, University of Muhammadiyah Malang, \\ Jl. Raya Tlogomas No.246, Malang, 65145, Indonesia \\ ${ }^{5}$ Program Study of Information Technology, University of Jember, Jl. Kalimantan 37, \\ Jember 68121, Indonesia
}

\begin{abstract}
The aim of this research is to determine the performance of PV panels, wind turbines, battery storage and power imported from the grid to the system which will ensure a reliable energy supply, as well as the technical feasibility of a smart microgrid system. Indonesia's renewable energy potential for electricity reaches $443 \mathrm{GW}$, where solar energy is the largest potential, namely $4.8 \mathrm{KWh} \mathrm{m}^{-2}$ or equivalent to $112000 \mathrm{GWp}$, but only $10 \mathrm{MWp}$ has been utilized. The most basic problem in this system, namely, the uncertainty of wind energy and solar energy, one of the most vital factors in the optimal size of a renewable energy-based smart microgrid system is the reliability of the system being built. The method used in this research is to collect data on the availability of wind energy and solar energy as well as load analysis on the smart microgrid system. As a result, the resulting power output was $6.2 \mathrm{MWh}$ during the experiment. The highest average Performance Ratio (PR) of the solar energy power generation system, namely $77 \%$ in February 2020. Optimized with Battery Life (OBL) model produces a power output of $102.4 \mathrm{kWh}$ and has an overall system efficiency of $81.92 \%$.
\end{abstract}

Key words: Clean energy, optimized with battery life, load analysis, performance ratio, technical assessment of energy availability

\section{Introduction}

Indonesia has high renewable energy potential. Based on data from the Ministry of Energy and Mineral Resources (KESDM), Indonesia's renewable energy potential for electricity

\footnotetext{
*Corresponding author: Kamaruddinabd@gmail.com
} 
reaches $443 \mathrm{GW}$, where solar energy is the greatest potential, namely $4.8 \mathrm{KWh} \mathrm{m}^{-2}$ or equivalent to $207 \mathrm{GWp}$, but only $78 \mathrm{MWp}$ has been utilized. While the potential for wind energy at wind speeds of more than $4 \mathrm{~m} \mathrm{~s}^{-1}$ is $60 \mathrm{GW}$ with an installed capacity of $3.1 \mathrm{MW}$ $[1,2]$, while the national electrification ratio until September 2019 has only reached $98.86 \%$, where the lowest electrification ratio is mostly in rural areas rural areas that are difficult to reach [3,4]. The conventional grid system is arguably outdated, in order to catch up with the fast growing demand for electrical energy. Global climate change is getting worse every year, this makes electric power industry scientists competing to create innovative systems to replace the existing electricity grid. Development of renewable energy is one of the seven national focuses and is included in one of the national research agendas. On the other hand, the use of a system that implements a smart or smart grid system is a promising development in the future, hence it can increase energy use effectively. In a smart grid system, all variables from the power plant to the end user side will be monitored and controlled continuously. This means that all systems must have complete control [5-8].

The technology that is being intensively developed now is the Smart grid or smart power grid system, according to the United States Department of Energy (DoE), that the smart grid is an integration of sensing technology, control methods, and communication on the existing power system. From this definition, one of the main parts of the Smart Grid system is to have a functioning communication system, so that all variables from the generation side to the end user side can be monitored in real-time and then a communication medium that can send real-time data is required.

One of the communication media commonly used is the internet. Also, the communication technology that is being developed intensively at this time is the Internet of Things (IoT), where this system allows all things to be connected together in internet services so that it allows users to monitor in both directions [9]. Due to the uncertainty of the availability of wind and solar energy, one of the most vital factors in the optimal size of a renewable energy-based smart microgrid system is the reliability of the system built to meet energy load requirements. The data collected must be compatible with providing sufficient resolution. The main contribution of this paper is to use a technical assessment of energy availability in relation to the power generated to find out the performance of PV panels, wind turbines, battery storage, and power imported from the grid to the system which will ensure a reliable energy supply, as well as the technical feasibility of smart microgrid system.

\section{Smart microgrid in Indonesia}

Studies on renewable energy-based smart microgrids in Indonesia have been carried out by several researchers [3], where the system used is to combine energy from solar PV and generators with diesel fuel. Diesel power used is $1 \mathrm{~kW}$ and solar PV $1 \mathrm{~kW}$. The diesel fuel used consists of coconut oil and palm oil [5]. This simulation was carried out using HOMER and MATLAB for the installation of a smart microgrid to be installed in Pesisir Selatan Regency. From the final report on technological innovation [1], the Center for Energy Conversion Technology reported the installation and testing of a smart microgrid in the form of the installation of $10 \mathrm{~kW}$ roof top solar PV installed on the roof of an energy building in the Puspipek (Pusat Penelitian Ilmu Pengetahuan dan Teknologi - Research Center for Science and Technology) area, Serpong, Tangerang, Indonesia to represent the smart micro grid system in urban areas. The excess power generated can be supplied to the State Electricity Company (PLN - Perusahaan Listrik Negara) network. This smart grid system balances the energy supply and the energy load generated by using software management. 
For smart microgrid activities for rural areas, installation was carried out in Bilacenge village, West Sumba Regency, Sumba Island, Indonesia in collaboration with Japanese company Kyukendo using an Energy Management System (EMS) which is integrated with the SMG (Smart Microgrid) system. For the Sumba island, $500 \mathrm{kWp}$ is installed, which is connected directly to the State Electricity Company (PLN) network. The EMS that is implemented consists of three components of the Smart Meter Control System (SMCS), the Smart Power Management System (SPMS), and the Battery Monitoring Unit (BMU). EMS accepts the input electrical power generated by four groups of solar panels with a capacity of $100 \mathrm{kWp}$ each.

Several researchers plan to install a renewable energy-based smart microgrid on the STT PLN campus, West Jakarta, Indonesia, which combines the power from a $14.5 \mathrm{kWp}$ solar power plant (solar PV), a $20 \mathrm{~kW}$ wind power plant, a $16 \mathrm{kVa}$ Biomass power plant consisting of from a wad14 $\mathrm{kVa}$ waste gasifier and a $2 \mathrm{kVA}$ waste digester plus a $\mathrm{kWH}$ meter extraction system from the State Electricity Company (PLN) network and batteries [7].

\section{Research methods}

The smart microgrid system installation has been completed, which will then be followed by a performance test of the system, including the performance efficiency and performance of the control system. The results of this performance test study will be used as the basis for the feasibility techno-economic calculation of a system that can be used in areas that require electricity based on solar and wind energy. The schematic of the installed smart microgrid system is shown in Figure 1.

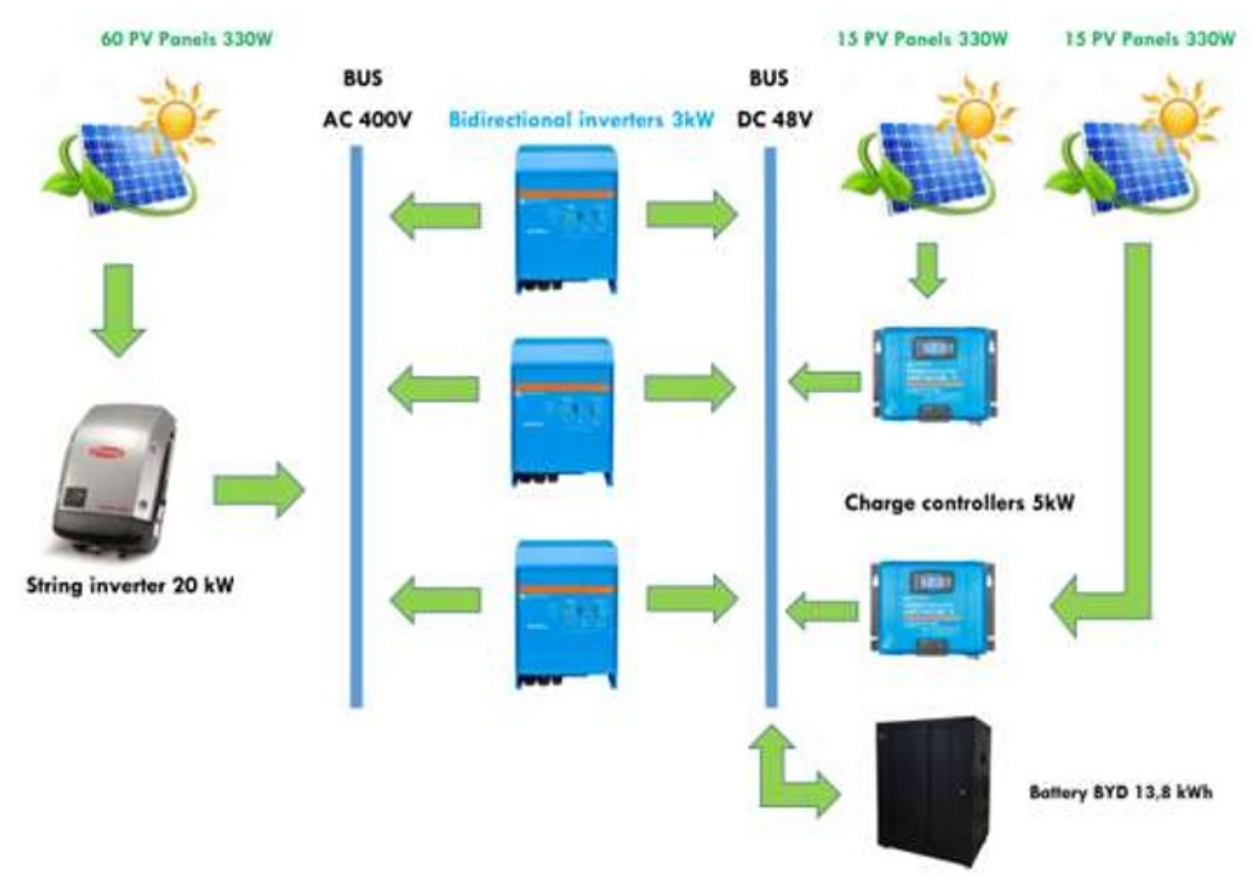

Fig. 1. Smart microgrid system. 


\subsection{Built-in smart microgrid system}

The Photovoltaic (PV) array consists of 90 modules with a capacity of $330 \mathrm{Wp}$ per module, which is divided into four series, namely $2 \times 30 \mathrm{PV}$ for on grid systems and $2 \times 15 \mathrm{PV}$ for battery charges. The system is supported by a $20 \mathrm{~kW}$ inverter connected directly to the grid, three units of 48/10 000/140-100/10 Victron QUATTRO inverters with one phase each, $13.8 \mathrm{kWh}$ lithium battery, MPPT Victron Smart Solar 150/100, cables and other supporting structures. The total area of the array is approximately $180 \mathrm{~m}^{2}$. Moreover, the PV Module is tilted at $7^{\circ}$ facing towards the North.

The installed wind turbine with a capacity of $6 \mathrm{~kW}$ has three blades and a wind guide. This turbine is supported by the Wind turbine tower P-750. This turbine also has an inverter which is connected to the smart microgrid system.

\subsection{Weather station}

Measurement of the potential for solar energy and wind energy in the Darma Persada University, East Jakarta campus environment using weather station instruments. The amount of solar radiation and wind speed can be read in real time using Davis Instruments Weatherlink software.

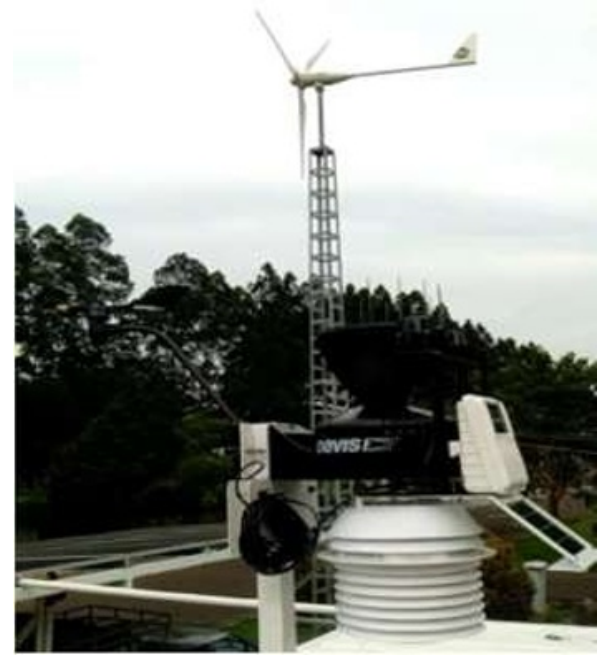

Fig. 2. Weather station.

\subsection{Solar energy and wind energy}

This section discusses basic computation theory, including defining a series of concepts, terms and variables used in evaluation. The number of obstacles that affect the wind speed and cause the wind turbine to not rotate, hence the wind energy in this system is neglected.

\subsubsection{Power}

The electric power generated by solar cells when exposed to light is calculated from the ability to produce voltage when given a load and current through the load at the same time. This is as represented on the current-voltage (I-V) curve in Figure 3. 
The power $\left(\mathrm{W}_{\text {peak }}\right)$ generated by the Solar Power Plant to meet energy needs is calculated by Equation 1 [6] :

$$
P_{\text {peak }}=A x S_{\text {peak }} \times \eta_{P V}
$$

Where $\mathrm{A}$ is the area of the PV array, $\mathrm{S}_{\text {peak }}$ is the Peak Solar Insulation $\left(1000 \mathrm{~W} \mathrm{~m}^{-2}\right)$ and $\eta_{\mathrm{PV}}$ is the efficiency of the solar panels.

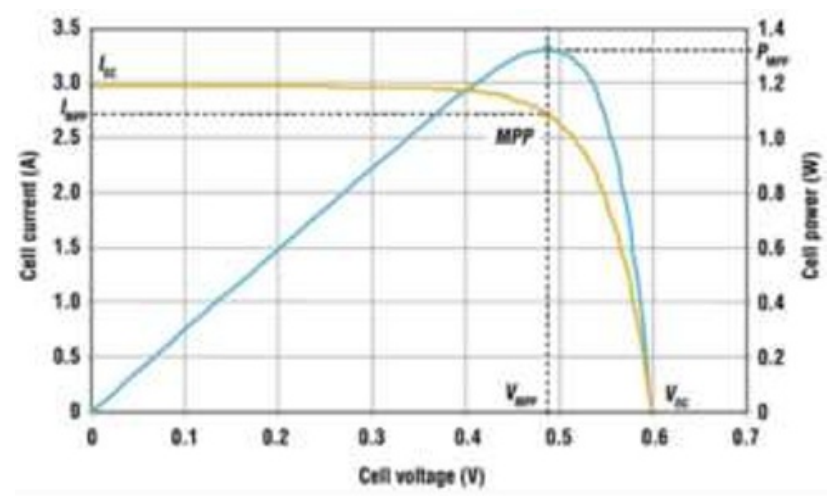

Fig. 3. The current-voltage (I-V) Curve [10].

The curve shows when the current and voltage are at the maximum power point, it will produce the maximum output power $\left(\mathrm{P}_{\mathrm{MPP}}\right)$. The voltage at the Maximum Power Point $\left(\mathrm{V}_{\mathrm{MPP}}\right)$ is less than the open circuit voltage $\left(\mathrm{V}_{\mathrm{OC}}\right)$ and the current at $\mathrm{I}_{\mathrm{MPP}}$ is lower than the short circuit current $\left(\mathrm{I}_{\mathrm{SC}}\right)$.

\subsubsection{Solar cell efficiency}

The efficiency of daily $\left(\eta_{\mathrm{PV}}, \mathrm{d}\right)$, monthly $\left(\eta_{\mathrm{PV}}, \mathrm{m}\right)$, and annual $\left(\eta_{\mathrm{PV}}, \mathrm{y}\right)$ of the PV arrays, respectively, is given in Equation 2:

$$
\eta_{P V, d}=\frac{E_{P V, d}}{E_{r, d}}
$$

$\mathrm{E}_{\mathrm{PV}, \mathrm{d}}$ is the daily energy $(\mathrm{kWh})$ produced by the PV module and is given by Equation 3

$$
E_{P V, d}=\int^{t f}\left(V_{D C} x I_{D C}\right) d t
$$

where $\mathrm{V}_{\mathrm{DC}}$ and $\mathrm{I}_{\mathrm{DC}}$ are $\mathrm{DC}$ voltage $(\mathrm{V})$ and $\mathrm{DC}$ current $(\mathrm{A})$, ti and tf are the start time and end time $(\mathrm{h}), \mathrm{E}_{\mathrm{r}, \mathrm{d}}$ are the daily available energy $(\mathrm{kWh})$, which are defined as the daily radiation in the surface plane of the array when the inverter is connected to the grid and is calculated using Equation 4 : 


$$
E_{r, d}=\sum_{i=0}^{n}\left(E_{i} \times C\right)=\int_{t i}^{t f}(S \times A) d t
$$

where $\mathrm{C}=0$ if the inverter is outgoing and $\mathrm{C}=1$ if the inverter is operating, $\mathrm{n}$ is the total number of values recorded daily, $\mathrm{E}_{\mathrm{i}}$ is the total energy received on the surface plane of the array during one measured interval $(\mathrm{kWh}), \mathrm{S}$ is the solar radiation $\left(\mathrm{W} \mathrm{m}^{-2}\right)$, and $\mathrm{A}$ is the area of the PV array $\left(\mathrm{m}^{2}\right)$. Therefore, if $\mathrm{C}=0$ for $\mathrm{E}_{\mathrm{i}}<$ Inverter threshold, then the inverter is disconnected from the grid.

\subsubsection{Inverter efficiency}

The efficiency of the daily $\left(\eta_{\text {inv }}, d\right)$, monthly $\left(\eta_{\text {inv }}, m\right)$, and annual $\left(\eta_{\text {inv }}, y\right)$ of the inverter is calculated by the Equation 5 :

$$
\eta_{i n v, d}=\frac{E_{G r i d, d}}{E_{P V, d}}
$$

where $\mathrm{E}_{\text {grid }}$ is the output of AC energy $(\mathrm{kWh})$ obtained from the receiving and sending measures $\left(E_{1}-E_{2}\right)$, where $E_{1}$ is the reading of the measuring instrument at the start of daily data acquisition and $E_{2}$ is the reading of the measuring instrument at the end of the daily data acquisition, Egrid, $\mathrm{d}$ is also the daily active energy at the output of the inverter $(\mathrm{kWh})$, and it can be calculated using the Equation 6 :

$$
E_{\text {Grid }, d}=\frac{E_{1}+E_{2}}{2}
$$

Where, $E_{1}=$ Total power of each phase (initial time) $\times\left(t_{\text {end }}-t_{\text {initial }}\right),(\mathrm{kWh})$. $\mathrm{E}_{2}=$ Total power of each phase $($ end time $) \times\left(\mathrm{t}_{\text {end }}-\mathrm{t}_{\text {initial }}\right),(\mathrm{kWh})$

\subsubsection{System efficiency}

The efficiency of the daily ( $\eta$ sys, d), monthly ( $\eta$ sys, m) and annual ( $\eta$ sys, $y$ ) of the systems can be evaluated using the Equation 7 :

$$
\eta_{s y s, d}=\frac{E_{\text {Grid }, d}}{E_{r, d}}
$$

In order to compare the results of different PV systems, two other parameters are needed, namely: final result $\left(\mathrm{Y}_{\mathrm{f}}\right)$ and performance ratio $(\mathrm{PR})$. The final result $\left(\mathrm{Y}_{\mathrm{f}}\right)$ is defined as the annual or daily system output energy divided by $\mathrm{W}_{\mathrm{p}, \mathrm{c}}$, where $\mathrm{W}_{\mathrm{p}, \mathrm{c}}$ represents the previous peak power estimate of the array under the Standard Testing Conditions (STC). Thus the daily, monthly and yearly final results are calculated using the Equation 8:

$$
Y_{f, d}=\frac{E_{G r i d, d}}{W_{p, c}}
$$

The daily performance ratio $\left(\mathrm{PR}_{\mathrm{d}}\right)$ is defined as the ratio between the daily final result and the daily global irradiation in the surface plane of the array $E_{i, d}$ given in the Equation 9

$$
P R_{d}=Y_{f, d} x \frac{G_{S T C}}{E_{i, d}}
$$


where $\mathrm{G}_{\mathrm{STC}}$ is the radiation below the STC. PR allows a comparison between the performance of different PV systems taking into account all parameters such as: location, tilt angle, orientation, nominal power, shading dust, etc.

\section{Result and discussion}

\subsection{Generation performance}

The overall performance of the smart microgrid system must also be measured from the performance of the energy source generated. A summary of the results of the generation performance from solar energy is summarized in Table 1.

Table 1. Summary of performance in $5 \mathrm{mo}$

\begin{tabular}{ccccc}
\hline \multicolumn{5}{c}{ Table 1. Summary } \\
Bulan & $\begin{array}{c}\text { EPV } \\
\mathrm{kWh}\end{array}$ & $\begin{array}{c}\mathrm{E}_{\text {Grid }} \\
\mathrm{kWh}\end{array}$ & $\begin{array}{c}\mathrm{Y}_{\mathrm{f}} \\
\mathrm{kWh} \mathrm{kWp}^{-1}\end{array}$ & $\begin{array}{c}\mathrm{PR} \\
\%\end{array}$ \\
\hline Oct-19 & 792.9 & 744.4 & 3.3 & $66 \%$ \\
\hline Nov-19 & 614.7 & 572.3 & 2.8 & $55 \%$ \\
\hline Dec-19 & 1511.1 & 1403.5 & 2.7 & $53 \%$ \\
\hline Jan-20 & 1596.5 & 1472.9 & 2.8 & $56 \%$ \\
\hline $\begin{array}{c}\text { Feb-20 } \\
\text { (by date 24) }\end{array}$ & 1605.7 & 1465.2 & 3.9 & $77 \%$ \\
\hline
\end{tabular}

Installation and testing of each component of the renewable energy-based smart microgrid system was carried out in September 2019. As a result, the power generated by the PV module is recorded to determine the system performance daily, monthly, and yearly. The experiments in October and November had a lower total power output than in December, January and February, namely $792.9 \mathrm{kWh}$ and $614.7 \mathrm{kWh}$, respectively. This is because some components experience errors and system testing. In the last 3 mo, the system is quite stable, because all the components are working properly. The error in the smart microgrid system can be seen in Figure 4.

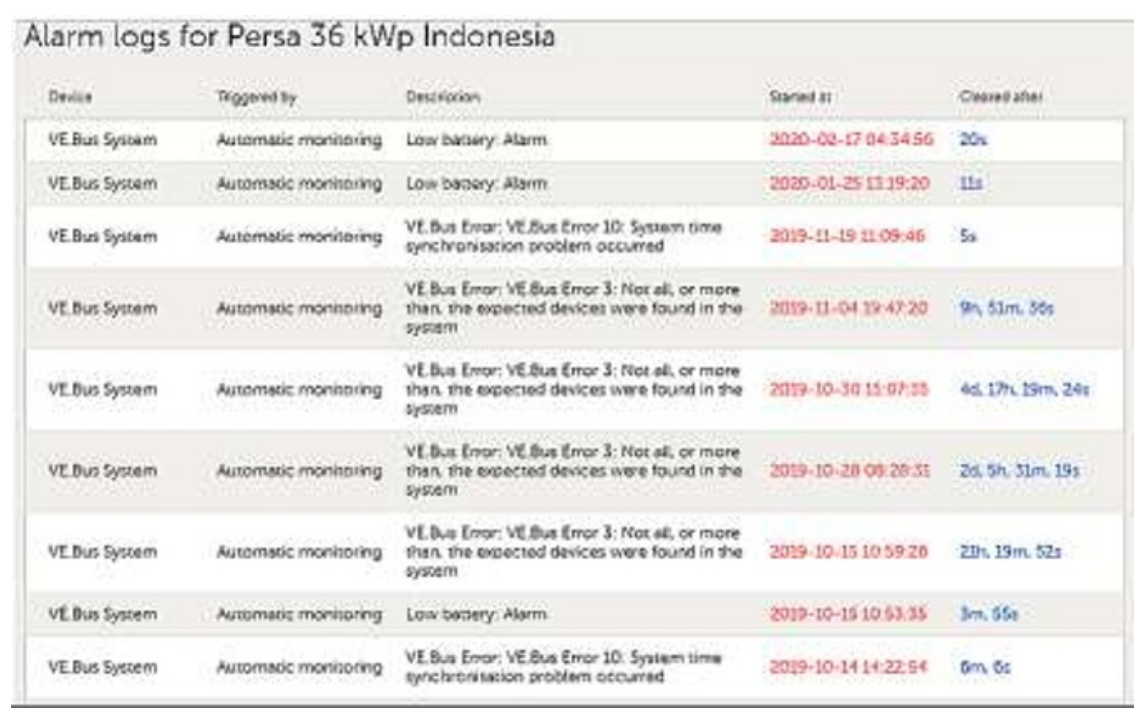

Fig. 4. Alarm monitoring of smart microgrid system faults. 
On the other hand, the influence of weather is the rainy season in the area where the research starts from early November to January, hence it affects the average system output energy $\left(\mathrm{Y}_{\mathrm{f}}\right)$ daily, which is $(2.7$ to 2.8$) \mathrm{kWh} \mathrm{kWp}^{-1}$. The influence of weather also affects the Performance Ratio (PR) of the average generation system, namely between $53 \%$ to $56 \%$. The highest Performance Ratio (PR) was $77 \%$ in February 2020.

\subsection{Technical feasibility analysis of smart microgrid system}

The smart microgrid system was tested using two optimization models. The first model is Optimized with Battery Life (OBL) and the second model is Optimized without Battery Life (OWBL). The results, as shown in Table 2, that the Total Production of the Optimized without Battery Life (OWBL) model is greater than the Optimized with Battery Life (OBL) model, namely $102.40 \mathrm{kWh}$ and $86.49 \mathrm{kWh}$, respectively.

Table 2. Total Production of different optimization models.

\begin{tabular}{|c|c|c|c|c|c|c|c|c|c|}
\hline \multirow{2}{*}{$\begin{array}{l}\text { Smart } \\
\text { Microgrid } \\
\text { System }\end{array}$} & \multirow{2}{*}{$\begin{array}{c}\mathrm{E}_{\mathrm{i}, \mathrm{d}} \\
{\left[\mathrm{kWh} \mathrm{m}^{-2}\right]}\end{array}$} & \multicolumn{4}{|c|}{$\mathrm{E}_{\mathrm{pv}, \mathrm{d}}[\mathrm{kWh}]$} & \multirow{2}{*}{$\begin{array}{c}\text { Total } \\
\text { Production } \\
{[\mathrm{kWh}]}\end{array}$} & \multirow{2}{*}{$\begin{array}{c}\eta_{\mathrm{pv}, \mathrm{d}} \\
\%\end{array}$} & \multirow{2}{*}{$\begin{array}{c}\eta_{\text {inv,d }} \\
\%\end{array}$} & \multirow{2}{*}{$\begin{array}{r}\eta_{\text {sys }, \mathrm{c}} \\
\%\end{array}$} \\
\hline & & $\begin{array}{l}15 \\
\mathrm{PV}\end{array}$ & $\begin{array}{l}15 \\
P V\end{array}$ & $\begin{array}{l}30 \\
\mathrm{PV}\end{array}$ & $\begin{array}{l}30 \\
\text { PV }\end{array}$ & & & & \\
\hline OBL & 4.2 & 15.78 & 17.27 & 35.03 & 34.32 & 102.4 & $11 \%$ & $99.98 \%$ & 81.92 \\
\hline OWBL & 4.5 & 5.76 & 5.27 & 38.1 & 37.37 & 86.49 & $\begin{array}{c}9.35 \\
\%\end{array}$ & $99.97 \%$ & 69.19 \\
\hline
\end{tabular}

Figure 5 - A1 \& A2, describes the smart microgrid system that is set in the Optimized with Battery Life model (OBL). This causes the PV production generated in a day to be less productive. In this optimization model, the production of the $2 \times 15 \mathrm{PV}$ circuit is only focused on charging the battery, the electric current is cut off by the Solar Charger when the battery is $100 \%$. As shown in the graphs in Figures 5 - A1 \& A2, the current is cut off when the radiation approaches peak solar radiation $\left(S_{\text {peak }}\right)$, hence $2 \times 15$ PV only produces $11 \mathrm{kWh}$ per day as shown in Table 2.

Figure 5 - B1 \& B2, describes the smart microgrid system that is set in the Optimized without Battery Life (OWBL) model. In this model, PV works to charge the battery and transmit directly to the grid. When the battery is in $100 \%$ state, the Solar Charger continues to drain the power generated by the PV. This causes the production of PV produced in a day to be more productive compared to the system mode in Figures 5 - A1 \& A2. The power generated by $2 \times 15 \mathrm{PV}$ in this system mode is $32 \mathrm{kWh}$ per day with an overall system efficiency of $81.92 \%$ as shown in Table 2 .

The total power generated during testing from October 2019 to February 2020 resulted in a PV power output of 6.2 MWh which was used for the water pump load of $55 \%$ of the total PV production power. Due to the limited capacity of the battery installed in the smart microgrid system, the consumption of electrical energy for loads (Consumers) at night relies on electrical energy from the grid. During the data collection period, the energy used by Grid for loads was $37 \%$, which was mostly used at night. Meanwhile, during the day, the electricity consumption for loads by electricity comes from solar energy, which is $63 \%$ of the total load. 


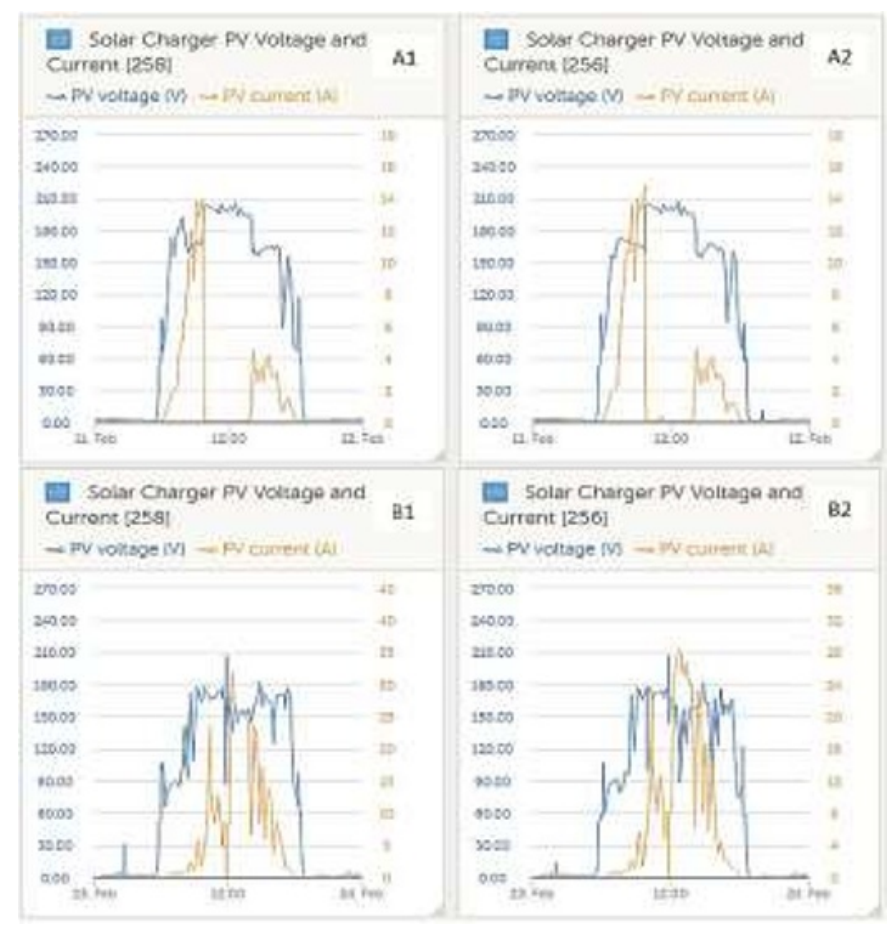

Fig. 5. (A1 \& A2) Optimized with Battery Life, (B1 \& B2) Optimized without Battery Life.

Table 3. Power transmission to the smart microgrid system.

\begin{tabular}{lccccccc}
\hline \multirow{1}{*}{ Item } & $\begin{array}{c}\text { Grid to } \\
\text { battery } \\
(\mathrm{kWh})\end{array}$ & $\begin{array}{c}\text { Grid to } \\
\text { consumers } \\
(\mathrm{kWh})\end{array}$ & $\begin{array}{c}\text { PV to } \\
\text { consumers } \\
(\mathrm{kWh})\end{array}$ & $\begin{array}{c}\text { PV to } \\
\text { battery } \\
(\mathrm{kWh})\end{array}$ & $\begin{array}{c}\text { PV to } \\
\text { grid } \\
(\mathrm{kWh})\end{array}$ & $\begin{array}{c}\text { Battery } \\
\text { to grid } \\
(\mathrm{kWh})\end{array}$ & $\begin{array}{c}\text { Battery to } \\
\text { consumers } \\
(\mathrm{kWh})\end{array}$ \\
\hline $\begin{array}{l}\text { Transmisi Daya } \\
{[\mathrm{kWh}]}\end{array}$ & 147.04 & 1991.21 & 2560.92 & 1307.12 & 2318.4 & 8.39 & 830.74 \\
\hline $\begin{array}{l}\text { PV Produksi } \\
{[\mathrm{kWh}]}\end{array}$ & & & 6186.44 & & & \\
\hline
\end{tabular}

Total Beban

(Consumers)

[kWh]

Persentase

Beban

(Consumers)
5382.87

\begin{tabular}{lll}
\hline $\begin{array}{l}\text { Grid X Systems } \\
{[\mathrm{kWh}]}\end{array}$ & 147.04 & 2326.79 \\
\hline
\end{tabular}

Information : Grid = National Electricity Company (PLN) electricity network.

The excess of PV production during the day, due to the load of the water pump which has a power of only $3 \mathrm{~kW}$, it is set by the system to be automatically transmitted to the grid network. The amount of power transmitted to the grid is $2.3 \mathrm{MWh}$. Meanwhile, the control room of the smart microgrid system supplied by Grid to operate system components at night is $147 \mathrm{~kW}$ or $6 \%$ of the power sent by the smart microgrid system to the Grid (State Electricity Company (PLN) network) [13]. 


\section{Conclusion}

The highest average Performance Ratio (PR) of the solar power generation system, which is $77 \%$ in February 2020. Optimized with Battery Life (OBL) models produces a power output of $102.4 \mathrm{kWh}$ and has a system efficiency of $81.92 \%$, greater than Optimized without Battery Life (OWBL) model that produces $86.49 \mathrm{kWh}$ of power with an overall system efficiency of $69.19 \%$. Overall, the smart microgrid system can operate properly. An error in the system that occurs once in January and February for only a few seconds can automatically return to normal immediately, due to the power transmission system regulated by Smart Microgrid.

The authors would like to thank Dr. Tomás Domínguez, as CEO of the KEMTECNIA Company, Spain, who provided the equipment used in this research.

\section{References}

1. BPPT. Inovasi teknologi smart grid. Laporan akhir BPPT, [Smart grid technology innovation. BPPT final report], No. 5884.001, Jakarta: BPPT (2017). [in Bahasa Indonesia]. http://b2tke.bppt.go.id/images/Documents/PPID/SetiapSaat/N\%20\%20Hasil\%20Kegiatan/2016/5864.007.001\%20\%20Inovasi\%20Teknologi\%20Smart\%20Grid.pdf

2. DEN. Perpres nomor 22 tahun 2017 rencana umum energi nasional. [Presidential Decree number 22 of 2017 the national energy general plan]. [in Bahasa Indonesia]. [Online] from: https://www.esdm.go.id/assets/media/content/content-rencana-umumenergi-nasional-ruen-1.pdf (2017). [Accessed on 1 January 2017]

3. Y.S. Indartono, I.K. Raksowardojo, T. Rachmilda, B. Yuliarto, A. Susandi, Smart micrigrid berbasis energi terbarukan [Renewable energy based smart micrigrids]. Pusat Penelitian Energi Baru Terbarukan ITB (2017). [in Bahasa Indonesia]. https://multisite.itb.ac.id/ppebt/wp-content/uploads/sites/118/2016/07/Smart-MicrigridBerbasis-Energi-Terbarukan.pdf

4. A. Pribadi. Tumbuh 3 persen per tahun, rasio elektrifikasi triwulan III capai 98.86 persen pemerataan. [Growing 3 percent per year, the electrification ratio in the third quarter reached 98.86 percent of equalization]. Kementerian Energi dan Sumber Daya Mineral (ESDM) [in Bahasa Indonesia]. [Online] from: https://www.esdm.go.id/id/media-center/arsip-berita/tumbuh-3-persen-per-tahun-rasioelektrifikasi-triwulan-iii-capai-9886-persen (2019). [Accessed on 4 November 2019]

5. R. Rauf. Jurnal Nasional Teknik Elektro, 2,2:79-85(2013). [in Bahasa Indonesia]. http://jnte.ft.unand.ac.id/index.php/jnte/issue/view/12

6. K. Sopian, S. Shaari, N. Amin, R. Zulkifli, M. Nizam, A. Rahman. International Journal of Engineering and Technology, 4(1):57-65(2007). [in Bahasa Indonesia].

https://www.researchgate.net/publication/228412573_Performance_of_a_gridconnected_photovoltaic_system_in_Malaysia

7. H. Suyatno, A. Hariyanto. Sutet, 7,1:63-67(2018). [in Bahasa Indonesia]. https://sttpln.e-journal.id/sutet/article/view/167

8. A. C. Swastika, R. Pramudita, R. Hakimi. IoT-based smart grid system design for smart home. Proceedings - ICWT 2017: 3rd International Conference on Wireless and Telematics 2017, (Palembang, Indonesia, 2017), p. 49-53. https://ieeexplore.ieee.org/document/8284137

9. R. Pramudita, F.I. Hariadi, A.S. Achmad. Development of IoT authentication mechanisms for microgrid applications. 2017 International Symposium on Electronics 
and Smart Devices, ISESD 2017, (Yogyakarta, Indonesia, 2017).

https://doi.org/10.1109/ISESD.2017.8253297

10. V. Quaschning. Understanding Renewable Energy Systems. New York: Routledge (2016). https://www.routledge.com/Understanding-Renewable-EnergySystems/Quaschning/p/book/9781138781962

11. H. Susanto, K. Abdullah, A.S. Uyun, S.M. Nur, T.M.I. Mahlia, MATEC Web of Conferences 164:1-17(2018). https://www.matecconferences.org/articles/matecconf/abs/2018/23/matecconf_icesti2018_01012/mateccon f icesti2018 01012.html

12. H. Susanto, R.H. Setyobudi, Y. Chan, S.M. Nur, E. Yandri, J. Burlakovs, et al., IOP Conf. Series: Earth and Environmental Science, 490:012009(2020). https://iopscience.iop.org/article/10.1088/1755-1315/490/1/012009/pdf

13. E. Yandri, Sol. Energy Mater. Sol. Cells, 201:10066(2019). https://www.sciencedirect.com/science/article/pii/S0927024819303952 